\title{
Facilitating Reading Javanese Letters Skill with a Multimodal Javanese Digital E-Book
}

\author{
Nur Hanifah Insani", Hardyanto Hardyanto, Joko Sukoyo \\ Department of Javanese Language and Literature, Universitas Negeri Semarang, Semarang, Indonesia \\ "Corresponding author.Email: hanifahnurinsani@mail.unnes.ac.id
}

\begin{abstract}
The Covid-19 pandemic changed the learning system drastically from a conventional system (face to face) to online learning. This paper describes how to make a multimodal Javanese Digital e-book to improve reading Javanese letters. The Multimedia Development Life Cycle (MDLC) was used as the research and development method. The MDLC method consists of six steps: concept, design, material collecting, assembly, testing, and distribution. The source was the animal stories from Serat Campur Bawur. The data were collected by a literature study and providing a questionnaire to 32 students in the Javanese literature program of Universitas Negeri Semarang as the research participants. The data were analyzed by descriptive qualitative with exposure and making data conclusion. The result of this study was the development of a multimodal Javanese digital e-book. The materials included in this e-book were the history and the structure of Javanese letters, two animal stories completed with video animation, which were equipped by quiz and evaluation test of each chapter. Most of the students felt it easier to learn the material of reading Javanese letters with this book. The multimodal Javanese digital e-book can be the alternative solution to teach the materials in the online learning system.
\end{abstract}

Keywords: e-book, Online learning, Javanese letters, multimodal

\section{INTRODUCTION}

Javanese script is one of the Indonesian scripts that must be preserved. Unfortunately, the ability of Indonesian people to read the Javanese script, especially the Javanese themselves, is weaker. Few people can read Javanese scripts well anymore. It feels like there has been a generation break in the millennial generation and even generation $\mathrm{Z}$, who have become increasingly blind to Javanese script. Currently, Javanese script is less popular to learn than foreign scripts, such as the Korean Hangeul script.

Many factors cause the weakening of the existence of Javanese script in the archipelago. The limitation of Javanese script reading sources in the digital realm is one of the factors driving the disconnection of the ability to master Javanese script in the young generation. Javanese script reading books widely circulated among the wider community can even be said to be non-existent. Javanese script writings intact in a book are still in the form of Javanese manuscripts. Javanese script reading books have not appeared again to this day; even this can be said to be an empty room. There are many learning resources about Javanese script developed in studies; unfortunately, the existing products have never been followed up by the developers, so they cannot be helpful for the wider community. Another factor that causes the low ability to read Javanese script is the untrained community to use Javanese script as a daily reading and writing activity. The Javanese script, which should be the mother script, was increasingly losing its echo because of people's ignorance of the Javanese script.

The depletion of spaces for the use of Javanese script, which is still limited to the formality of learning in the classroom, further exacerbates the destruction of Javanese script in the lives of the Javanese people themselves. Javanese is even considered one of the most challenging subjects for most students. Of the various Javanese language materials presented, Javanese script became the most challenging subject in the students' minds. In general, students find it difficult to distinguish the form of one script from another; they still also have to adjust the guidelines of Javanese script writing [1]. 
The other research showed that the subject of Javanese script received less attention from students because the teacher's teaching methods and learning media used were still conventional, so they were less attractive to students because of the less interaction [2]. The initial pre-test of the Javanese letter reading course for Javanese Literature students at Semarang State University class of 2020 also found that $90 \%$ of students were still not fluent in reading Javanese script. It was a profound dilemma, considering that students who are accepted into the Javanese literature study program should have mastered the reading of Javanese scripted texts well.

The problems related to improving students' ability to read Javanese scripts have been done frequently. Unfortunately, the current research results have not been followed up further for one reason or another. Several studies have been carried out regarding this matter. Setiawan et al. conducted research to analyze the problematic implementation of learning to write Javanese script in the classroom, starting from planning and performance to evaluation at the end of the lesson [3]. The study recommended implementing the result being used in Javanese language learning at the high school level. Praheto et al. have also investigated one of the learning methods to read Javanese script, which is said to be effective when applied in Javanese language learning, called the transliteration model [4]. In principle, with this transliteration model, students inevitably must read the Javanese text, so they will be able to distinguish the form of each character. Unfortunately, there is no definite measurement result on how effectively this method was applied in learning Javanese generally, especially in Javanese script material.

One of the efforts that can be done to increase the younger generation's interest in reading Javanese script is by developing learning media according to the times. The first step that can be taken is by looking at the current distribution of the population in Indonesia. From the composition of the Indonesian population by generation category, most of Indonesia's population currently comes from Generation Z (born 1997-2012, estimated age 8-23 years), which is 74.93 million people or $27.94 \%$ of the Indonesian population [5]. Gen Z has a unique character that is different from the previous generation. Some main characters of Gen $\mathrm{Z}$ are phygital (physical and digital), fear of missing out, hyper customization, competitiveness, economist, and do it yourself [6].

The unique and increasingly diverse characteristics of Gen $\mathrm{Z}$ make it necessary to have various learning strategies that are used to accommodate the teaching and learning communication process in the 21 st century. The development of learning strategies for Gen $\mathrm{Z}$ must use mobile technology as much as possible and applications that can be opened on tablets or smartphones. The main reason because they were born in the digital world, so they cannot be separated from existing technological developments. For Gen Z, using technology as a whole element of life, including education, is a must because they want to get the best access to collaborate with the outside world [7]. Of course, the learning process must also be packaged in a modern and fun form with the help of technology.

The COVID-19 pandemic has forced the implementation of the learning process to be done online. One type of learning media that can be developed to help the teaching and learning process during online learning is a multimodal e-book. This multimodal-based e-book is very suitable for learning studies that involve knowledge that must be sought in the field. Technological developments that are growing rapidly from day to day have led to the presence of many of the latest innovations from existing technology. One of the innovations that we can find currently developing in virtual learning is the preparation of a multimodal-based electronic book (e-book).

In online learning, multimodal Javanese e-books can be a solution for transferring Javanese script media. Suppose in the pre-pandemic period; students had to come to the library or museum directly to access Javanese texts, with the multimodal Javanese e-book. In that case, students could still practice reading Javanese texts online. This multimedia component transfers Javanese script texts from print media to digital media and packages them in complex multimedia forms. The process of reconstructing printed Javanese script texts into dynamic texts in the form of multimodal Javanese e-books has never been developed before. The results of this media development certainly bring fresh air for the preservation of Javanese script and add freshness to the product of Javanese language learning media types. Therefore, this study aims to analyze developing multimodal Javanese e-books.

\section{METHOD}

Research and development (R\&D) design is used to compile learning media in an e-book. The Javanese ebook multimodal design process uses the ADDIE Model in a cycle and consists of five stages, namely Analysis, Design, Development, Implementation, and Evaluation [8]. The picture of the stages of the ADDIE research procedure in this study can be seen in Figure 1. The selection of this model is based on a systematic view of the model form following the instructional theory of learning design development. From a series of research planned procedures, this research stage was limited to the expert validation stage because it followed the focus of the research objectives. The data of this study were sourced from the text of Serat Campur Bawur. At the same time, the research subjects were 32 students of the 
Javanese Literature Study Program, Universitas Negeri Semarang, two media experts, and two material experts.

Data collection techniques through questionnaires with Google Form are used in the expert validation, implementation, and evaluation stages. The results of the questionnaire assessment were measured using the Likert scale. Observations and interviews were also conducted to obtain media needs analysis data. Data analysis technique with qualitative descriptive method is used to describe the process of media design and development. Quantitative data in the form of expert assessment scores are added up and then divided by the maximum score multiplied by one hundred percent so that data is obtained in percentages.

\section{RESULT AND DISCUSSION}

The whole process of developing multimodal Javanese e-book learning media is carried out through seven product development stages. The product development process begins with an analysis of learning media needs, initial design, product development, expert assessment, implementation in a limited space, evaluation, and final product refinement. The analysis of the product development process is limited to the stage of expert assessment.

\subsection{Learning Media Analysis}

The media development process begins with the analysis phase. A media needs analysis is an important step that must be done before developing a new media. The data from the media need analysis was obtained from the observation process and the distribution of questionnaires to the Javanese Literature students at Semarang State University. The observation stage was carried out at the beginning of the lecture on reading Javanese letters by giving a pre-test of reading material Javanese letters packaged through the Kahoot game. The pre-test results showed that the average student's answer in answering ten questions was $23 \%$. This percentage was in a low category, indicating that almost all students still have difficulty reading Javanese texts.

Based on the results of observations and interviews, it can be concluded that students need Javanese script learning media that is interesting, effective, easy to understand in language, and easy to operate either through laptops or smartphones. The flexibility of learning media is essential because online learning requires students to access all materials through the internet network. Multimodal Javanese E-book is offered to be a solution to the needs of students in optimizing learning to read Javanese letters. This multimedia is designed interactively with a multimodalbased approach so that students can be active and participatory in creating a conducive atmosphere for the teaching and learning process.
The development of e-books as interactive learning resources supports students' reading skills. The results of previous research show that e-books improve reading skills and understanding of words [9] and their meanings [10], which are delivered directly through a computer. The E-book is an effective and efficient tool for improving learning outcomes by teaching and learning objectives [11].

This multimodal-based Javanese script electronic book belongs to interactive multimedia development. The characteristics of interactive learning media are contained in the interactive quiz component, which is directly guided by the tutor (lecturer) in playing it. In addition, students can also interact directly with tutors through the google classroom feature embedded in the e-book. In contrast, the multimodal characteristics in the development of this media lie in the diversity of media types presented in e-books. This multimodal Javanese ebook does not only contain Javanese texts, but the existing text is also combined with images, audio, and video. This multimedia combination is expected to make it easier for students to learn Javanese script material independently. Students will be easier to follow the lecture process to read Javanese letters. Reference to word visualization in a narrative context is a more challenging activity than just an expository activity so that it can train students to more easily understand its meaning [12]. The development of learning media by the needs can provide a new teaching and learning atmosphere for students and lecturers.

\subsection{An Interactive Multimodal Javanese eBook}

Multimodal Javanese e-book is included in the category of textbook development. The design of multimodal Javanese script e-book was compiled based on the results of media needs analysis. The components of a good textbook include having a systematic structure, referring to specific $\mathrm{CP} /$ Competencies, motivating readers according to learning needs, anticipating learning difficulties, providing exercises and summaries, being able to be used for independent study, using communicative language, and being given guidance how to use it [13]. The existence of e-books itself has advantages related to ease of access, interactivity, multimodal content, prevention of book loss, and minimal space for physical needs [14]. The multimodal Javanese e-book prototype was designed with a high multimodality content base, has interactivity, and is easily accessible to a broad audience only with the help of the internet. This e-book can also be downloaded for offline use, apart from being accessed online. Overall, multimodal Javanese e-books were arranged as attractively as possible to meet the student's learning needs and at the same time overcome students' difficulties in learning the material for reading Javanese letters. 
Multimodal-based learning multimedia can stimulate students to practice independently both inside and outside the classroom. It can be optimized in the design of learning media based on Gen $\mathrm{Z}$ characteristics such as the use of attractive designs (eye-catching) both from the selection of images, graphics, use of colors, font types, giving animations, and various kinds of interactive videos. In the 21 st century, visual text design plays a vital role in understanding the concepts being taught [15]. It is crucial to consider in developing learning media for Gen $\mathrm{Z}$, who likes to make connections with other people in terms of media interactivity with students. The student needs spaces to interact directly with teachers, friends, or with the learning media itself. Students can be asked to use digital technology, such as iMovie, Windows Movie Maker, VoiceThread, to collect assignments that have been submitted [15]. Students can be directed to use Tiktok, Reels on Instagram to train students' creativity and open-mindedness in understanding the material. The multimodal principle provides opportunities for students to use technology in exploring constructs to understand the context of learning materials.

The standard completeness of textbooks is a complementary part of the contents of a book. The completeness section of the text consists of a cover page, book identity page, manual page using the e-book, preface, table of contents, the body divided into chapters or sections, author biodata, bibliography, and glossary. The standard structure chapter (body) is the core standard in a book. The structure of each chapter was composed of instructional objectives, material exposure, supporting information in the form of a concise glossary, and the learning dynamics of students. It forms personal assignments collected with Google Classroom, conclusions/summaries, practice questions designed in the form of quizzes using Quizizz and Wordwall, and bibliography. The design of the presentation of the material was presented in the form of text, audio, or video originating from YouTube uploads.

These various types of learning modes then make this Javanese electronic book called multimodal. The multimodality of text makes the media interactive because it can make someone interact in learning through digital media [16]. The multimodal nature itself is structured to accommodate various types of student learning, including visual, auditory, and visual-auditory learners. The use of digital technology in using multimodal media supports the learning process of students with various personality backgrounds [17]. A multimodal approach can foster students' sociocognitive abilities that can contribute to acquiring knowledge-based skills and interactions with the outside world [18]. The multimodal approach is proven to help improve students' ability to read the meaning of a text [19].
An interactive multimodal Javanese e-book is promising; it provides features that support this interactive nature from the voiceover that accompanies the narrative exposure of each material. Voice over is used to emphasize information which is also commonly used by a professional to promote products in electronic media [20]. Voiceovers and texts designed with the suitable script method can stimulate students to practice independently without a teacher [21].

Several other components refer to the category of interactive multimedia. Another feature that forms the basis for designing interactive multimedia lies in instructional videos displayed on the material summary menu. Text instructions through text hyperlinks were used to explain the meaning of difficult words and contain interactive concepts. The preparation of multiple-choice quizzes through Quizizz also includes interactive media functions. The entire interaction of images, videos, and examinations can be interactive if they are arranged using instructional design principles [14].

In this study, the multimedia and interactive components were arranged in such a way into a Javanese e-book multimodal design. Combining these two components were considered to support conceptual understanding, increase knowledge retention, and support skills training [14]. Students can use all of the components provided to practice self-disclosure and interaction with the built text situation. By using collaborative learning tools such as classroom blogs, social media (such as YouTube), and other applications, educators can help 21st-century learners move through various learning levels according to the goals and expected outcomes [22]. It is no less important to optimize the benefits of this interactive multimedia, of course, based on the design and navigation of the ebook that must be easy to run. The design and use of teaching materials were fundamental because student interaction was built to strengthen the actual learning process [28]. In general, multimodal Javanese e-books received a positive response as an alternative learning material for reading Javanese scripts.

\subsection{Media Validation Results}

The validation process determines the feasibility of the designed media and the prepared material. Validators consist of two media experts from Informatic Engineering Education and Fine Art Education and two material experts from Javanese Language Education.

Media assessment by material experts found that the average score of the two validators on the feasibility of the material was $93.39 \%$ ("very valid"). These results indicate that the Javanese e-book multimodal fulfills the quality according to the textbook standards set by the BSNP as a textbook with local content. It can be seen 
from the material's content, which describes the local wisdom of the Javanese script in the texts presented. The development of e-books has also fulfilled the pedagogical structure of the learning process. This ebook can be a good textbook because it is prepared by considering an excellent pedagogical design, a clear relationship with the overall curriculum, and students' learning styles at the age of 18, written in simple, inspiring, and aspirational language. The most important thing has a strong relationship with the material to be discussed [24].

In the distribution of media assessment questionnaires by media experts, eighteen assessment indicators consist of two significant aspects: software aspects and visual communication aspects. The average percentage of the assessment of the two media experts was $86.11 \%$ (very valid); it indicates that the multimodal Javanese e-book has fulfilled the components of the software assessment and visual communication aspects. It also shows that the developed multimedia can be easily used by students independently.

Media visualization design needs to be considered in developing learning media. Experience shows that using graphic elements to visualize essential parts of content is very helpful for students in learning [24]. The final assessment criteria related to the visual communication aspect lie in the animated elements displayed according to the learning objectives. Animations were designed using clear and attractive images and were easy to operate. The various modes of learning embedded in this e-book can enable students to develop different kinds of technical skills. Students are encouraged to recognize themselves through the multimodal world that has been created and has accessible space [25].

\section{CONCLUSION}

Based on the research and discussion, it can be concluded that, first, the multimodal Javanese e-book that was developed was "very valid" both in terms of material and media quality. Second, the Javanese e-book multimodal product, apart from functioning as a learning medium, has also met the eligibility criteria as textbooks to be used as a source of learning material for reading Javanese letters. It can be seen from the expert validation results and the limited product implementation response to students who are very enthusiastic and feel helped by the media products development. Third, the development of multimodal Javanese e-book meets the criteria of compelling and interactive multimedia as material resources in online learning. So, the complex elements in this e-book make this media relevant to students' characteristics in this era and can be used as an alternative to reading Javanese letters book resources during online learning.

\section{ACKNOWLEDGMENTS}

This study is supported by the DIPA research fund Universitas Negeri Semarang, project number 81.18.5/UN37/PPK.4.2/2021.

\section{REFERENCES}

[1] B. M. Setyawati, Si Bawa' (Sinau Basa Jawa) Belajar dengan Senang, Hati menjadi Riang, in Sembur Tutur: Mrih Budaya Mekar Sempulur, Mulyana and D. D. Hartanto, Eds. Yogyakarta: Spasi Book, 2021, pp. 340-362.

[2] Y. F. Avianto and T. A. S. Prasida, Pembelajaran Aksara Jawa untuk Siswa Sekolah Dasar dengan Menggunakan Media Board Game, Aksara, vol. 30, no. 1, p. 133, Jul. 2018, doi: 10.29255/aksara.v30i1.223.133-148.

[3] B. Setiawan, P. A. W Wibowo, F. Azzahrah, P. R. Harjani, and K. Saddhono, Study of Javanese Script Writing Learning in Senior High Schools in Boyolali Regency, 2019, doi: 10.4108/eai.298-2019.2288906.

[4] B. E. Praheto, F. Baskara, and B. Utomo, Transliteration Method In Learning Reading Of The Javanese Script, Proceeding PGSD UST Int. Conf. Educ., vol. 2, no. 0, pp. 32-36, 2019, [Online]. Available: http://www.jurnal.ustjogja.ac.id/index.php/ICE/ article/view/6177.

[5] T. Redaksi, GeN-Z, Pendidikan Harus Bertransformasi, LPMP Jatim, 2021. https://lpmpjatim.kemdikbud.go.id/site/detailpos t/gen-z-pendidikan-harus-bertransformasi (accessed Sep. 01, 2021).

[6] D. Stillman and J. Stillman, Gen Z @ Work: How the Next Generation Is Transforming the Workplace. Harper Business, 2017.

[7] J. O. Otieno and S. M. Nyambegera, Millennials and Generation Z Employees are here: Is your Organization ready?, J. Lang. Technol. Entrep. Africa, vol. 10, no. 2, pp. 68-85, 2019.

[8] W. Dick, L. Carey, and J. O. Carey, The Systematic Design of Instruction, Eighth. United States of America: Pearson, 2015.

[9] O. Korat and A. Shamir, Direct and Indirect Teaching: Using E-Books for Supporting Vocabulary, Word Reading, and Story Comprehension for Young Children, J. Educ. Comput. Res., vol. 46, no. 2, pp. 135-152, 2012, doi: 10.2190/EC.46.2.b.

[10] O. Korat, M. Tourgeman, and O. Segal-Drori, 
E-Book Reading in Kindergarten and Story Comprehension Support, Read. Writ., no. 0123456789, 2021, doi: 10.1007/s11145-02110175-0.

[11] K.-Y. Tang, Paradigm Shifts of E-booksSupported learning: Evidence from the a Cocitation Network Analysis with an Education Focus (2010-2019), Comput. Educ., vol. 175, no. June, p. 104323, 2021, doi: 10.1016/j.compedu.2021.104323.

[12] S. B. Neuman, R. Flynn, K. Wong, and T. Kaefer, Quick, Incidental Word Learning in Educational Media: All Contexts are Not Equal, Educ. Technol. Res. Dev., vol. 68, no. 6, pp. 2913-2937, 2020, doi: 10.1007/s11423-02009815-z.

[13] S. Arifin, Teknik \& Strategi Menulis Buku dan Modul Ajar, 2017. Accessed: Sep. 13, 2021. [Online]. Available: http://bpm.umg.ac.id/aset/images/download/M1 -Teknik-Strategi-BA(1-8-2017).pdf.

[14] N. P. Morris and J. Lambe, "Multimedia Interactive eBooks in Laboratory Bioscience Education Neil," High. Educ. Pedagog., vol. 2, no. $1, \quad$ pp. 28-42, 2017, doi: 10.1080/23752696.2017.1338531.

[15] J. E. Flynn and W. Lewis, "Multimodal Composition in Teacher Education: From Consumers to Producers," in Essentials of Teaching and Integrating Visual and Media Literacy, D. M. Baylen and A. D'Alba, Eds. Cham: Springer International Publishing, 2015, pp. 147-163.

[16] E. S. Tobias, "Let's Play! Learning Music Through Video Games and Virtual Worlds," in Creativities, Technologies, and Media in Music Learning and Teaching, G. E. McPherson and G. F. Welch, Eds. Oxford University Press, 2018, p. Chapter 14.

[17] S. Sofkova Hashemi and K. Cederlund, "Making Room for the Transformation of Literacy Instruction in the Digital Classroom," J. Early Child. Lit., vol. 17, no. 2, pp. 221-253, Jun. 2017, doi: 10.1177/1468798416630779.

[18] C. Gregori-Signes, "Digital Storytelling and Multimodal Literacy in Education," Porta Linguarum, vol. 22, no. Juni, pp. 237-250, 2014.

[19] J. Rowsell, "Maureen Walsh, Multimodal Literacy: Researching Classroom Practice," J. Early Child. Lit., vol. 12, no. 2, pp. 223-227,
2012, doi: $10.1177 / 1468798411425672$.

[20] R. Medrado, L. P. Ferreira, and M. Behlau, "Voice-over: Perceptual and Acoustic Analysis of Vocal Features," J. Voice, vol. 19, no. 3, pp. 340-349, 2005, doi: 10.1016/j.jvoice.2004.04.008.

[21] A. Anindyarini, F. Rokhman, M. Mulyani, and . A., "Behavioristic Theory and Its Application in the Learning of Speech," KnE Soc. Sci., vol. 3, no. 9 , pp. 522-530, 2018, doi: 10.18502/kss.v3i9.2714.

[22] S. E. Smaldino, D. L. Lowther, and J. D. Russell, Instructional Technology and Media for Learning, Tenth., vol. 148. Pearson, 2014.

[23] S. E. Smaldino, D. L. Lowther, C. Mims, and James D. Russell, Instructional technology and media for learning, Eleventh. United States of America: Pearson, 2015.

[24] C. Stolker, Pedagogy: Teaching law students, in Rethinking the Law School: Education, Research, Outreach and Governance, Cambridge: Cambridge University Press, 2014, pp. 153-199.

[25] B. Dalton, Multimodal Composition and the Common Core State Standards, Read. Teach., vol. 66, no. 4, pp. 333-339, 2012, doi: 10.1002/TRTR.01129. 